University of Nebraska - Lincoln

DigitalCommons@University of Nebraska - Lincoln

\title{
Population Structure of Columbia Spotted Frogs (Rana luteiventris) is Strongly Affected by the Landscape
}

\author{
W. Chris Funk \\ University of Texas at Austin, Chris.Funk@colostate.edu \\ Michael S. Blouin \\ U.S. Geological Survey \\ Paul Stephen Corn \\ U.S. Geological Survey \\ Bryce A. Maxell \\ University of Montana - Missoula \\ David S. Pilliod \\ USDA Forest Service, dpilliod@usgs.gov
}

See next page for additional authors

Follow this and additional works at: https://digitalcommons.unl.edu/usgsstaffpub

Part of the Geology Commons, Oceanography and Atmospheric Sciences and Meteorology Commons, Other Earth Sciences Commons, and the Other Environmental Sciences Commons

Funk, W. Chris; Blouin, Michael S.; Corn, Paul Stephen; Maxell, Bryce A.; Pilliod, David S.; Amish, Stephen; and Allendorf, Fred W., "Population Structure of Columbia Spotted Frogs (Rana luteiventris) is Strongly Affected by the Landscape" (2005). USGS Staff -- Published Research. 659.

https://digitalcommons.unl.edu/usgsstaffpub/659

This Article is brought to you for free and open access by the US Geological Survey at DigitalCommons@University of Nebraska - Lincoln. It has been accepted for inclusion in USGS Staff -- Published Research by an authorized administrator of DigitalCommons@University of Nebraska - Lincoln. 


\section{Authors}

W. Chris Funk, Michael S. Blouin, Paul Stephen Corn, Bryce A. Maxell, David S. Pilliod, Stephen Amish, and Fred W. Allendorf 


\title{
Population structure of Columbia spotted frogs (Rana luteiventris) is strongly affected by the landscape
}

\author{
W. CHRIS FUNK, ${ }^{*}$ MICHAEL S. BLOUIN,+PAUL STEPHEN CORN, $\ddagger$ BRYCE A. MAXELL $§$ \\ DAVID S. PILLIOD, IISTEPHEN AMISH§ and FRED W. ALLENDORF* \\ *Division of Biological Sciences, University of Montana, Missoula, Montana 59812, USA, +Department of Zoology, Oregon State \\ University, 3029 Cordley Hall, Corvallis, OR 97331, USA, ‡US Geological Survey, Aldo Leopold Wilderness Research Institute, 790 \\ E. Beckwith Ave., Missoula, MT 59807, USA, §Wildlife Biology Program, College of Forestry and Conservation, University of \\ Montana, Missoula, MT 59812, USA, IIAldo Leopold Wilderness Research Institute, Rocky Mountain Research Station, USDA Forest \\ Service, 790 E. Beckwith Ave., Missoula, MT 59807, USA
}

\begin{abstract}
Landscape features such as mountains, rivers, and ecological gradients may strongly affect patterns of dispersal and gene flow among populations and thereby shape population dynamics and evolutionary trajectories. The landscape may have a particularly strong effect on patterns of dispersal and gene flow in amphibians because amphibians are thought to have poor dispersal abilities. We examined genetic variation at six microsatellite loci in Columbia spotted frogs (Rana luteiventris) from 28 breeding ponds in western Montana and Idaho, USA, in order to investigate the effects of landscape structure on patterns of gene flow. We were particularly interested in addressing three questions: (i) do ridges act as barriers to gene flow? (ii) is gene flow restricted between low and high elevation ponds? (iii) does a pond equal a 'randomly mating population' (a deme)? We found that mountain ridges and elevational differences were associated with increased genetic differentiation among sites, suggesting that gene flow is restricted by ridges and elevation in this species. We also found that populations of Columbia spotted frogs generally include more than a single pond except for very isolated ponds. There was also evidence for surprisingly high levels of gene flow among low elevation sites separated by large distances. Moreover, genetic variation within populations was strongly negatively correlated with elevation, suggesting effective population sizes are much smaller at high elevation than at low elevation. Our results show that landscape features have a profound effect on patterns of genetic variation in Columbia spotted frogs.
\end{abstract}

Keywords: Columbia spotted frog, dispersal, effective population size, gene flow, landscape genetics, microsatellite, Rana luteiventris

Received 5 October 2004; revision received 4 November 2004; accepted 4 November 2004

\section{Introduction}

Describing the effects of landscape features on genetic variation is essential for understanding how landscapes shape dispersal, gene flow, population divergence, and speciation (Manel et al. 2003). For example, many models of population divergence and speciation invoke specific landscape features such as rivers, mountains, or habitat gradients as the primary cause of divergence (Wallace 1852;

Correspondence: W. C. Funk, Present address: Integrative Biology, University of Texas, 1 University Station C0930, Austin, TX 78712, USA; Fax: 512 4719651; E-mail: wcfunk@mail.utexas.edu
Smith et al. 1997; Lougheed et al. 1999). However, because little is known about the effects of these features on genetic variation, it is difficult to predict their potential for causing population divergence. Recent studies have made important contributions to our understanding of the effects of landscape features on genetic variation in plants (Bockelmann et al. 2003), butterflies (Keyghobadi et al. 1999), and wolves (Geffen et al. 2004).

The landscape may have particularly strong effects on genetic variation in amphibians because amphibians are generally thought to have poor dispersal abilities (Blaustein et al. 1994). Evidence for low dispersal in amphibians comes from field studies showing high philopatry (Daugherty \& 
Sheldon 1982; Driscoll 1997) and genetic studies showing low levels of gene flow among population (Larson et al. 1984; Driscoll 1998; García-Parris et al. 2000; Shaffer et al. 2000; Tallmon et al. 2000; Monsen \& Blouin 2003). However, other studies on amphibian dispersal suggest that amphibian movement may not always be so limited (Breden 1987; Berven \& Grudzien 1990; Marsh \& Trenham 2001; Trenham et al. 2001). Therefore, there may be potential for high gene flow in some species or among some populations (Berry 2001; Newman \& Squire 2001; Squire \& Newman 2002; Lampert et al. 2003).

Mountain ridges are one landscape feature that may act as important barriers to dispersal and gene flow in amphibians. Because some amphibians are subject to high evaporative water loss because of their permeable skin (Duellman \& Trueb 1994), they may tend to move along riparian corridors rather than over drier mountain ridges. Or, if ridges are high enough, they may be impassable because they exceed the physiological limits of some species. Lougheed et al. (1999) found that a historic mountain ridge acted as an important barrier to gene flow in a frog (Epipedobates femoralis), supporting the hypothesis that ridges act as barriers for some amphibians. Support for this hypothesis also comes from biogeographical evidence showing that the ranges of some amphibians are bounded by mountains (Lynch \& Duellman 1997).

Elevational differences among amphibian populations may also restrict dispersal and gene flow. First, dispersal might be restricted from low to high elevation populations simply because of the energetic costs of moving up steep slopes. Second, even if dispersal is not restricted, premating barriers to gene flow may restrict gene flow between low and high elevation populations. Premating barriers to gene flow may include lower survival of dispersers or lower mating success of dispersers as a result of elevational differences in breeding phenology (Howard \& Wallace 1985) or differences in sexually selected traits such as advertisement calls (Narins \& Smith 1986; Lüddecke \& Sánchez 2002).

Mountain ridges, elevation, and other landscape features may also influence the distribution of amphibian populations across the landscape. In many ecological and genetic studies of pond and lake breeding amphibians, ponds or lakes are considered to be synonymous with randomly mating populations (Gill 1978; Sjögren 1991; Hecnar \& M'Closkey 1996; Tallmon et al. 2000). This is an appealing definition of a population because ponds and lakes are discrete physical units bounded by the shoreline. However, data showing substantial interpond movements in amphibians suggest that populations may sometimes include more than a single pond (Berven \& Grudzien 1990; Alford \& Richards 1999; Marsh \& Trenham 2001; Trenham et al. 2001). Moreover, much attention has recently been given to the fact that pond-breeding amphibians require upland terrestrial habitats for foraging and overwintering, suggesting that geographical units larger than single ponds are necessary for amphibian persistence (Semlitsch 2003). Resolving the spatial extent of amphibian populations using genetic data is one useful approach for determining the most appropriate geographical unit for management (Moritz 1994).

Columbia spotted frogs (Rana luteiventris) are pondbreeding frogs distributed from the southern Rocky Mountains northward through southeastern Alaska (Green et al. 1996, 1997). They are found in a variety of habitat, ranging from low elevation wetlands to high elevation lakes. Field studies demonstrate that Columbia spotted frogs can move long distances, but the effects of these movements on fine-scale patterns of genetic variation remain unknown (Turner 1960; Reaser 1996; Pilliod et al. 2002; Funk et al. 2005). Columbia spotted frog populations appear stable except for isolated populations in the southern portion of the species' range in Nevada and Utah (Bos \& Sites 2001). However, the sister species of the Columbia spotted frog, the Oregon spotted frog (Rana pretiosa), has declined dramatically throughout its range in northern California, western Oregon and Washington, and southwestern British Columbia (Green et al. 1997) and is a candidate for listing under the US Endangered Species Act (ESA). Moreover, other members of the genus Rana in the western US such as the California red-legged frog (Rana aurora draytonii) and the mountain yellow-legged frog (Rana muscosa) have suffered dramatic declines as well and are already ESA-listed in all or parts of their ranges (Drost \& Fellers 1996; Davidson et al. 2001). The study of genetic variation in Columbia spotted frogs provides the unique opportunity to understand natural patterns of genetic variation in a species of western Rana in relatively undisturbed habitat in which populations have not undergone declines.

We investigated patterns of genetic variation at microsatellite loci within and among populations of Columbia spotted frogs to address three primary questions: (i) do ridges act as barriers to gene flow? (ii) is gene flow restricted between low and high elevation ponds? (iii) does a pond equal a randomly mating population? Our results show that the landscape has strong effects on genetic variation in Columbia spotted frogs. We develop a model to explain the patterns of genetic variation observed and discuss the evolutionary and conservation implications of the model.

\section{Materials and methods}

\section{Samples}

We sampled an average of 30 adult Columbia spotted frogs from each of 28 ponds and lakes (sites) across western Montana and Idaho for a total of 790 individuals using toe-clips (Table 1, Fig. 1; Heyer et al. 1994). We used a 


\begin{tabular}{|c|c|c|c|c|c|c|c|}
\hline Region & Basin & Site & UTM & Elev. (m) & $N$ & $H_{\mathrm{E}}$ & Alleles \\
\hline Cabinet \& & Keeler & 1 & $11575650 \mathrm{E} 5352125 \mathrm{~N}$ & 1581 & 28 & 0.50 & 24 \\
\hline Coeur & & 2 & 11 576062E 5354011N & 884 & 29 & 0.59 & 28 \\
\hline $\mathrm{d}^{\prime}$ Alene & & 3 & 11 579939E 5353638N & 785 & 19 & 0.63 & 31 \\
\hline \multirow[t]{9}{*}{ Mts., MT } & & 4 & $11580150 \mathrm{E} 5353173 \mathrm{~N}$ & 824 & 29 & 0.55 & 30 \\
\hline & & 5 & 11 579822E $5352880 \mathrm{~N}$ & 812 & 19 & 0.62 & 29 \\
\hline & Stanley & 6 & 11 580370E $5342957 \mathrm{~N}$ & 1485 & 27 & 0.40 & 21 \\
\hline & Marten & 7 & 11 587089E $5304715 \mathrm{~N}$ & 833 & 25 & 0.65 & 36 \\
\hline & & 8 & 11 587462E 5304851N & 819 & 55 & 0.66 & 36 \\
\hline & & 9 & 11 589970E 5304808N & 769 & 29 & 0.62 & 31 \\
\hline & & 10 & 11 590173E 5304507N & 839 & 25 & 0.65 & 32 \\
\hline & & 11 & 11 592072E 5303550N & 733 & 24 & 0.70 & 34 \\
\hline & & 12 & 11 593092E 5303102N & 769 & 30 & 0.64 & 34 \\
\hline Bitterroot & One Horse & 13 & 11 711404E $5171317 \mathrm{~N}$ & 2251 & 30 & 0.44 & 17 \\
\hline \multirow[t]{10}{*}{ Mts., MT } & N. Sweeney & 14 & 11 710259E $5168988 \mathrm{~N}$ & 2244 & 30 & 0.47 & 22 \\
\hline & & 15 & 11 710202E $5168893 \mathrm{~N}$ & 2241 & 30 & 0.46 & 23 \\
\hline & & 16 & 11 711573E 5168050N & 1982 & 30 & 0.43 & 18 \\
\hline & Valley & 17 & 11 723231E $5162021 \mathrm{~N}$ & 999 & 30 & 0.42 & 18 \\
\hline & S. Sweeney & 18 & 11 709043E $5165790 \mathrm{~N}$ & 2238 & 30 & 0.40 & 16 \\
\hline & Rock & 19 & 11 700017E 5099542N & 2133 & 30 & 0.39 & 15 \\
\hline & & 20 & 11 715702E 5106121N & 1250 & 25 & 0.50 & 22 \\
\hline & L. Rock & 21 & 11 702849E $5098795 \mathrm{~N}$ & 2256 & 21 & 0.32 & 17 \\
\hline & & 22 & 11 703869E $5098184 \mathrm{~N}$ & 2139 & 30 & 0.29 & 16 \\
\hline & & 23 & 11 705725E 5100021N & 1995 & 24 & 0.34 & 14 \\
\hline & Skyhigh & 24 & 11 688873E 4998211N & 2484 & 28 & 0.35 & 19 \\
\hline \multirow{4}{*}{ Crags, ID } & & 25 & $11688911 \mathrm{E} 4996632 \mathrm{~N}$ & 2463 & 22 & 0.38 & 20 \\
\hline & Bob & 26 & 11 690127E 4999150N & 2652 & 30 & 0.39 & 19 \\
\hline & Tiptop & 27 & 11 687947E 4995677N & 2548 & 31 & 0.26 & 15 \\
\hline & & 28 & 11 687637E 4994117N & 2560 & 30 & 0.23 & 11 \\
\hline
\end{tabular}

Map datum NAD27 was used for UTM coordinates. $N$ is the sample size, $H_{\mathrm{E}}$ is expected heterozygosity at the six microsatellite loci examined, and alleles is the total number of alleles observed. Site numbers correspond to the site numbers in Fig. 1.

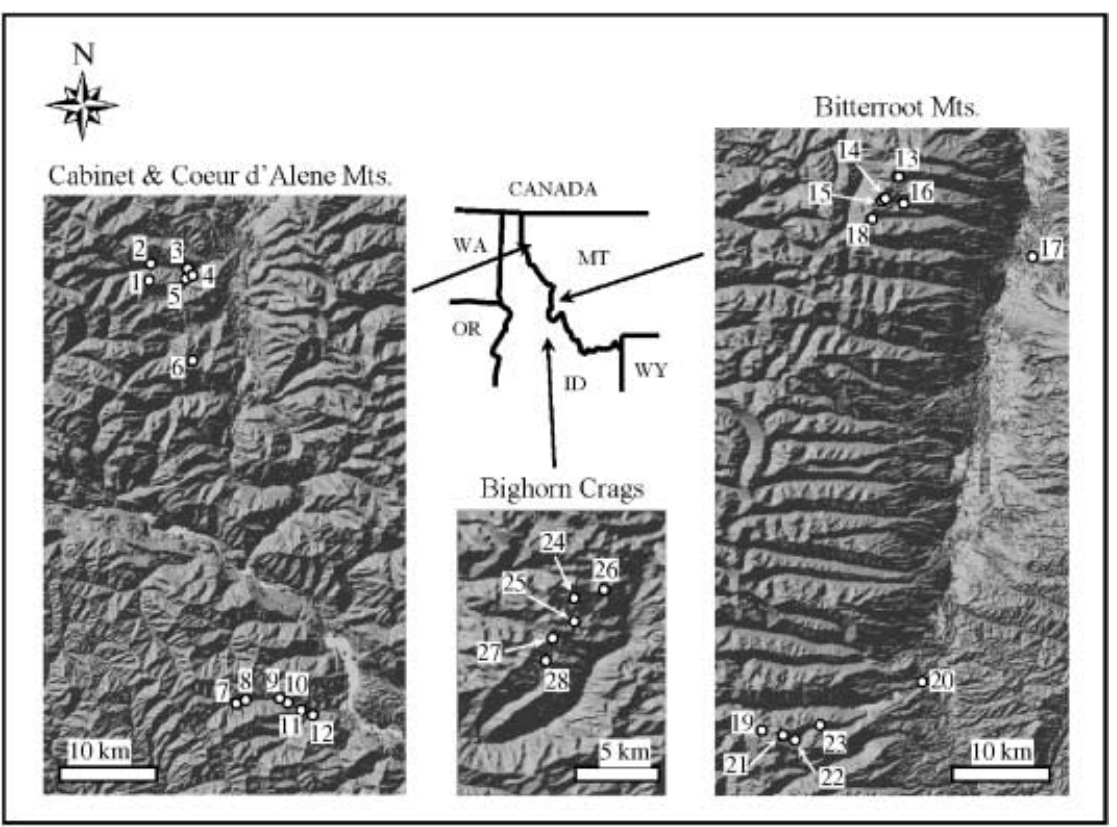

(c) 2005 Blackwell Publishing Ltd, Molecular Ecology, 14, 483-496
Table 1 Columbia spotted frog sample site information

Fig. 1 Location of Columbia spotted frog breeding ponds and lakes in Montana and Idaho, USA, sampled for microsatellite analysis. Site numbers correspond to the site numbers in Table 1. 
sampling scheme that allowed us to test the effects of mountain ridges and elevational differences on genetic variation. Specifically, sites were sampled in adjacent basins to allow us to test the effects of intervening ridges and at different elevations within basins to allow us to test the effects of elevational differences. Moreover, this sampling scheme was used in three different regions (Cabinet and Coeur d' Alene Mountains, Montana; Bitterroot Mountains, Montana; and Bighorn Crags, Idaho) to broaden the geographical scope of inference of the study.

We sampled adult frogs in the breeding season, or shortly thereafter, to make sure they were associated with the breeding population from the given pond rather than temporary seasonal migrants (Pilliod et al. 2002). In site number 17, tadpoles were sampled because no adults were found. In site number 18, juvenile frogs and hatchling tadpoles were sampled in addition to adult frogs to supplement the sample size. In this case, only a single hatchling was taken from each egg mass to avoid disproportionate sampling of a few families. Most sites were sampled in 2000, but some were sampled in 2002 and 2003.

\section{Microsatellites}

DNA was extracted using the PureGene kit (Gentra) following the manufacturer's instructions. We used six microsatellite loci that were developed originally for Oregon spotted frogs (Rana pretiosa) (Rp3, Rp15, Rp17, and Rp23) and Columbia spotted frogs (Rana luteiventris) (SFC134 and SFC139; Table 2; Blouin, unpublished). Allele size differences between some Rp15 alleles are not divisible by the repeat length of four because this locus has nonmicrosatellite insertion-deletions. Loci were amplified using the polymerase chain reaction (PCR) reagents described in Monsen \& Blouin (2003) and the annealing temperatures shown in Table 2. PCR was conducted in an
MJ Research PTC-100 thermocycler with a total reaction volume of $10 \mu \mathrm{L}$.

Amplified alleles were separated on $7 \%$ denaturing polyacrylamide gels and visualized using a Hitachi FMBIO-100 fluorescent imager. Allele sizes were determined relative to a standard base pair size ladder (MapMarkerLow, Bioventures). Previously amplified products were included on each gel to ensure consistent scoring of individuals across all gels.

\section{Data analysis}

Allele frequencies, exact probabilities for Hardy-Weinberg proportions, exact probabilities for genotypic disequilibrium, $F$-statistics, and exact probabilities of differentiation in allele frequencies were calculated using GENEPOP version 3.3 (Raymond \& Rousset 1995). Expected heterozygosities and allelic richness were calculated using FSTAT version 1.2 (Goudet 1995). Allelic richness is the number of alleles corrected for sample size (Petit et al. 1998). Linear regression analysis of expected heterozygosity vs. elevation and allelic richness vs. elevation was performed in MINITAB version 13.

We examined broad geographical subdivisions across all three regions using analysis of molecular genetic variance with $F_{\mathrm{ST}}$ (AMOvA; Excoffier et al. 1992) using ARLEQUIN version 2.001 (Schneider et al. 2000). We compared five alternative population groupings with AMOvA to test which grouping explained the greatest proportion of variance (Table 3).

We used two approaches to investigate the effect of landscape features on population divergence within regions. First, we examined pairwise $F_{\mathrm{ST}} \mathrm{s}$ to qualitatively assess the effects of mountain ridges and elevational differences on genetic divergence. Second, we used Mantel tests (Mantel 1967) and partial Mantel tests (Smouse et al. 1986) to examine

Table 2 Primer sequences, PCR annealing temperatures, product lengths, and number of alleles (out of 790 Columbia spotted frogs analyzed) for six microsatellite loci from Oregon spotted frogs (Rana pretiosa) (Rp loci) and Rana luteiventris (SFC loci)

\begin{tabular}{|c|c|c|c|c|c|}
\hline Primer & Repeat motif & Primer sequence ( $5^{\prime}$ to $\left.3^{\prime}\right)$ & Annealing temp $\left({ }^{\circ} \mathrm{C}\right)$ & Product length (bp) & No. alleles \\
\hline Rp3 & GATA & $\begin{array}{l}\text { F: 5'-GAAAGCAAAACTGGGAAAGTACATA-3' } \\
\text { R: 5'-CCTGAGAGCCATCCAATAAGTGCCA-3' }\end{array}$ & 45 & $187-223$ & 10 \\
\hline Rp15 & GATA & $\begin{array}{l}\text { F: 5'-CTTGATACAGTGTGCAAGAGGC-3' } \\
\text { R: 5'-ATACTCGTGATAGGGAGTTT-3' }\end{array}$ & 50 & $188-209$ & 8 \\
\hline Rp17 & GATA & $\begin{array}{l}\text { F: 5'-GTGTAGACAAACAAATGAAAGTCAG-3' } \\
\text { R: 5'-TCTCTACTTCCATCCAACCATTCC-3' }\end{array}$ & 50 & $114-210$ & 15 \\
\hline Rp23 & GATA & $\begin{array}{l}\text { F: 5'-ACATAGATACAATAGATAGATAGAC-3' } \\
\text { R: 5'-CACAGGAATGTAAAATCTGGCTTTC-3' }\end{array}$ & 52 & $183-203$ & 6 \\
\hline SFC134 & TACA & $\begin{array}{l}\text { F: 5'-TGGGAAAAGACTCTGTGGT-3' } \\
\text { R: 5'-AGGAAATGTGTGGAAGCAT-3' }\end{array}$ & 57 & $213-229$ & 5 \\
\hline SFC139 & TACA & $\begin{array}{l}\text { F: 5'-GGCATGGTTAAAGTGGAACTC-3' } \\
\text { R: 5'-TGCATGTCTGTAATGGACCTC-3' }\end{array}$ & 58 & $245-305$ & 16 \\
\hline
\end{tabular}




\begin{tabular}{|c|c|c|c|c|}
\hline Groups & $\begin{array}{l}\text { Number } \\
\text { of groups }\end{array}$ & $\begin{array}{l}\text { Variance } \\
\text { components }\end{array}$ & $\begin{array}{l}\text { Percentage } \\
\text { of variation }\end{array}$ & $P$-value \\
\hline \multirow[t]{3}{*}{ (1) Basins } & \multirow[t]{3}{*}{12} & Among groups & 17.6 & $<0.001$ \\
\hline & & Among sites & 3.8 & $<0.001$ \\
\hline & & Within sites & 78.6 & $<0.001$ \\
\hline \multirow[t]{3}{*}{ (2) High vs. low elevation } & \multirow[t]{3}{*}{2} & Among groups & 4.1 & 0.005 \\
\hline & & Among sites & 17.6 & $<0.001$ \\
\hline & & Within sites & 78.3 & $<0.001$ \\
\hline (3) Regions (Cabinet \& & \multirow[t]{4}{*}{3} & Among groups & 10.4 & $<0.001$ \\
\hline Coeur d'Alene Mts. vs. & & Among sites & 12.5 & $<0.001$ \\
\hline Bitterroot Mts. vs. & & Within sites & 77.0 & $<0.001$ \\
\hline \multicolumn{4}{|l|}{ Bighorn Crags) } & \\
\hline (4) Snake R. vs. Clark Fork & \multirow[t]{3}{*}{2} & Among groups & 14.7 & $<0.001$ \\
\hline \multirow[t]{2}{*}{ R. \& Kootenai R } & & Among sites & 13.6 & $<0.001$ \\
\hline & & Within sites & 71.7 & $<0.001$ \\
\hline \multirow{3}{*}{$\begin{array}{l}\text { (5) Snake R. vs. Clark Fork } \\
\text { R. vs. Kootenai R. }\end{array}$} & \multirow[t]{3}{*}{3} & Among groups & 12.5 & $<0.001$ \\
\hline & & Among sites & 12.0 & $<0.001$ \\
\hline & & Within sites & 75.5 & $<0.001$ \\
\hline
\end{tabular}

Table 3 Results from analysis of molecular variance (AMOVA) with sample sites grouped in different ways

All sites above $1400 \mathrm{~m}$ were considered high elevation sites and all sites below $1400 \mathrm{~m}$ were considered low elevation sites. Sites in Keeler and Stanley basins are part of the Kootenai River system; sites in Marten basin and the Bitterroot Mountains are part of the Clark Fork River system; and sites in the Bighorn Crags are part of the Snake River system.

the effect of straight-line distance, river distance, elevational differences, and mountain ridges on $F_{\mathrm{ST}}$ using FSTAT version 1.2. The natural logarithm of straight-line distances and river distances were used to linearize the relationship between distance and $F_{\mathrm{ST}}$. A pair of sites was considered to be separated by a mountain ridge if a straight line between the two sites intersected one or more ridges. Partial Mantel tests measure the effect of a variable on $F_{\mathrm{ST}}$ after controlling for another variable, analogous to partial correlation coefficients. We used partial Mantel tests to evaluate two alternative hypotheses concerning movement patterns in Columbia spotted frogs. First, to test the hypothesis that frogs primarily move along riparian corridors, but that elevational differences along rivers impede movement, we estimated the partial correlation between $F_{\mathrm{ST}}$ and elevation after controlling for river distance. Second, to test the hypothesis that frogs primarily move overland, but that ridges impede overland movement, we estimated the partial correlation between $F_{\mathrm{ST}}$ and mountain ridges after controlling for straight-line distance. The $\alpha$ value for each test was determined using a sequential Bonferroni adjustment (Rice 1989).

Finally, we used two methods to investigate how many ponds make up a 'randomly mating population', equivalent to a deme or subpopulation in the population genetics literature (Hartl \& Clark 1989). First, for each pair of ponds, we calculated the probability that allelic distributions are identical between ponds when all loci are combined (Sokal \& Rohlf 1981). The degrees of freedom (d.f.) for this test was 12, equivalent to two times the number of loci (Sokal
\& Rohlf 1981). If the exact probability of population differentiation across loci was greater than 0.01 , we considered the two ponds to be part of the same randomly mating population. Second, we used a Bayesian clustering approach implemented in STRUCTURE version 2.1 (Pritchard et al. 2000) to estimate the number of populations $(K)$ in a sample and to assign individuals to one or more of these populations (k). This approach assumes Hardy-Weinberg equilibrium (HWE) and linkage equilibrium between loci within populations. We used the admixture model which assumes gene flow among populations. The admixture model assigns a proportion of each individual's genome to each population $\left(q_{k}\right)$. We assigned sites to populations by calculating mean $q_{k} \mathrm{~s}$ for each site $\left(\bar{q}_{k}\right)$ and assigning each site to the population with the largest $\bar{q}_{k}$. For each basin or set of adjacent basins, we calculated the probability that there are from $K=1$ to the total number of sites sampled in the basin or set of adjacent basins. We ran five independent simulations for each $K$, used a burn-in length of 50,000 and a run length of 106 , and assumed correlated allele frequencies.

Tables of the genotypes used in our analyses are available upon request.

\section{Results}

\section{Variation within populations}

Genotypic frequencies generally conformed to the expected Hardy-Weinberg proportions. Fifteen of 151 tests for deviation from Hardy-Weinberg proportions were statistically 
significant $(P<0.05)$ which is greater than the seven tests expected to deviate by chance. However, after correcting for multiple tests, only site 17 deviated significantly from expected Hardy-Weinberg proportions at $R p 3$ with $F_{\text {IS }}=$ -0.579 indicating heterozygote excess. Heterozygote excess at site 17 is likely because of the sampling of tadpoles at this site which, as mentioned above, may only represent the reproductive contribution of a few adults. No loci had an excess of homozygotes as would be expected if there were null alleles.

Tests for linkage disequilibrium did not reveal any strong associations between loci. Twenty-eight out of 352 tests were significant $(P<0.05), 11$ more than the 17 significant tests expected by chance. Fourteen of the significant tests were between Rp3 and SFC139, consistent with weak linkage between these loci. After correcting for multiple comparisons, four associations remained significant: $R p 3$ and Rp17, Rp3 and SFC139, and Rp17 and SFC139 in site 7; and Rp3 and SFC139 in site 17. This suggests some degree of population subdivision within site 7 .

Overall levels of genetic variation within Columbia spotted frog populations varied substantially among populations and loci. The total number of alleles per site ranged from 11 alleles in site 28 to 36 alleles in sites 7 and 8 (Table 1). Average expected heterozygosity ranged from 0.23 in site 28 to 0.70 in site 11 (Table 1). The number of alleles per locus also varied substantially among loci, ranging from five alleles at SFC134 to 16 at SFC139 (Table 2).

Average expected heterozygosity and average allelic richness were strongly negatively correlated with elevation (Table 1, Fig. 2). The correlation coefficient between expected heterozygosity and elevation was $r=-0.88(P<0.001)$. The correlation coefficient between allelic richness and elevation was $r=-0.85(P<0.001)$. Expected heterozygosity and allelic richness were low at site 17 (unique in that only tadpoles were sampled), given the site's elevation (999 m a.s.l.), causing this site to act as an outlier.

\section{Divergence among populations}

Microsatellite analysis of the entire data set suggests that Columbia spotted frog sites tend to group with other sites in the same basin. This is reflected in the analysis of molecular genetic variance with basins explaining the most among-group variance (17.6\%; Table 3). The second best grouping is the Snake River (all sites in Bighorn Crags, Idaho) vs. the Clark Fork River and Kootenai River (all Montana sites; 14.7\%).

Microsatellite analysis within regions reveals that mountain ridges and elevational differences are associated with increased genetic divergence among sites. The isolating effect of mountain ridges can be seen by comparing pairwise $F_{\mathrm{ST}} \mathrm{S}$ between sites in adjacent basins with pairwise $F_{\mathrm{ST}}$ between sites within basins (Table 4, Fig. 1). For example, in the Cabinet Mountains, pairwise $F_{\mathrm{ST}}$ between sites 1 to 5 in
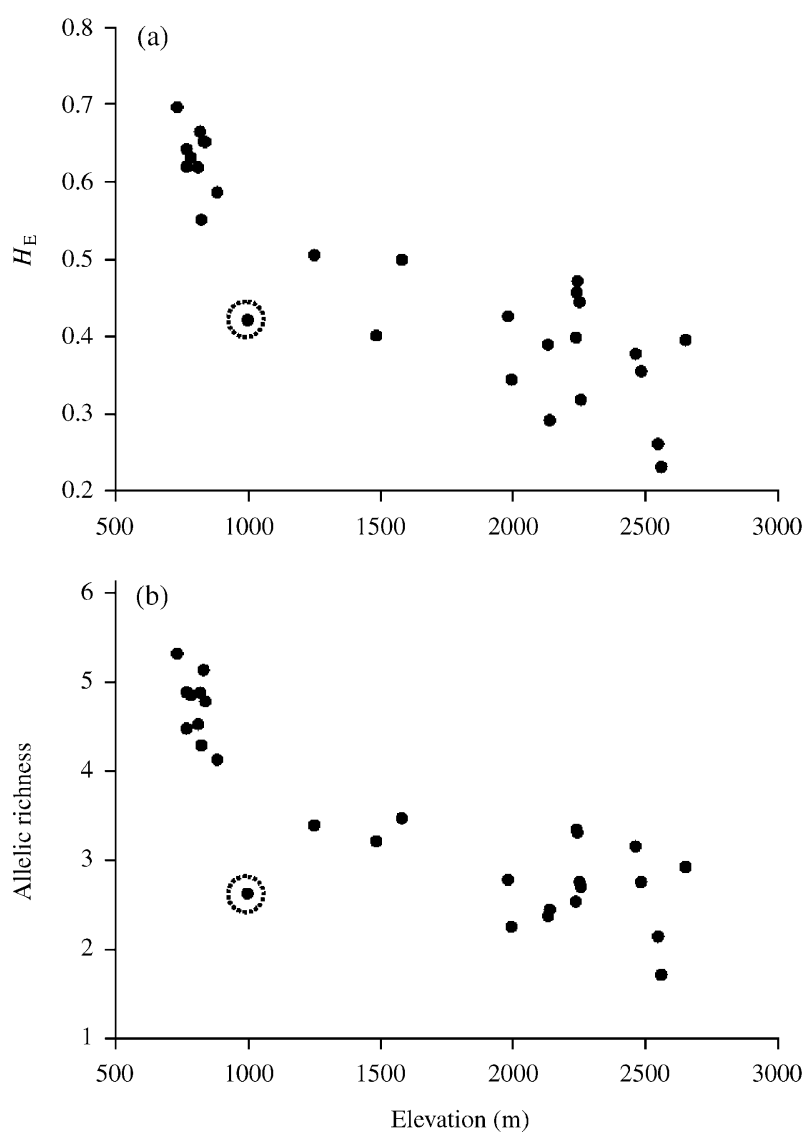

Fig. 2 Relationship between (a) mean expected heterozgyosity $\left(H_{\mathrm{E}}\right)$ and elevation and (b) mean allelic richness and elevation for all 28 sites analysed. Site 17 where only tadpoles were sampled is indicated with a dashed circle.

Keeler Creek and site 6 in Stanley Creek are much higher than pairwise $F_{\mathrm{ST}}$ between sites 1 to 5 within Keeler Creek (Table 4). High pairwise $F_{\mathrm{ST}}$ are also seen between sites 19 in Rock Creek and sites 21 to 23 in Little Rock Creek in the Bitterroot Mountains and between sites 24 and 25 in Skyhigh basin and sites 27 to 28 in Tiptop basin in the Bighorn Crags (Table 4). High pairwise $F_{\mathrm{ST}}$ s between sites on opposite sides of ridges contrast with low $F_{\mathrm{ST}}$ s between low elevation sites separated by large distances. For example, low elevation sites in Keeler Creek (sites 2 to 5) are less differentiated from low elevation sites in Marten Creek (sites 7 to 12), separated by a straight-line distance of approximately $50 \mathrm{~km}$, than they are from site 6 on the other side of a ridge only $10 \mathrm{~km}$ away (Table 4). Ridges do not always isolate populations, however, as can be seen from the low pairwise $F_{\mathrm{ST}} \mathrm{S}$ between sites 13 in One Horse Creek and sites 14 to 16 in North Fork Sweeney Creek in the Bitterroot Mountains (Table 4).

The isolating effects of elevation can also be seen by examining pairwise $F_{\mathrm{ST}} \mathrm{s}$ between high and low elevation sites within basins (Table 4, Fig. 1). For example, pairwise 


\begin{tabular}{|c|c|c|c|c|c|c|c|c|c|c|c|c|c|c|c|c|c|c|c|c|c|c|c|c|c|c|c|c|}
\hline \multirow[b]{3}{*}{ Site } & \multicolumn{28}{|l|}{ Site } \\
\hline & \multicolumn{5}{|c|}{ Keeler } & \multirow{2}{*}{$\frac{\text { Stanley }}{6}$} & \multicolumn{6}{|c|}{ Marten } & \multirow{2}{*}{$\begin{array}{l}\text { One } \\
\text { Horse } \\
13\end{array}$} & \multicolumn{3}{|c|}{ N. Sweeney } & \multirow{2}{*}{$\frac{\text { Valley }}{17}$} & \multirow{2}{*}{$\begin{array}{l}\text { Sweeney } \\
\text { S. } \\
18\end{array}$} & \multicolumn{2}{|l|}{ Rock } & \multicolumn{3}{|c|}{ L. Rock } & \multicolumn{2}{|c|}{ Skyhigh } & \multirow{2}{*}{$\frac{\text { Bob }}{26}$} & \multicolumn{2}{|c|}{ Tiptop } \\
\hline & 1 & 2 & 3 & 4 & 5 & & 7 & 8 & 9 & 10 & 11 & 12 & & 14 & 15 & 16 & & & 19 & 20 & 21 & 22 & 23 & 24 & 25 & & 27 & 28 \\
\hline 1 & - & $* * *$ & $* * *$ & $* * *$ & $* * *$ & $* * *$ & $* * *$ & $* * *$ & $* * *$ & $* * *$ & $* * *$ & $* * *$ & $* * *$ & $* * *$ & $* * *$ & $* * *$ & $* * *$ & $* * *$ & $* * *$ & $* * *$ & $* * *$ & $* * *$ & $* * *$ & $* * *$ & $* * *$ & $* * *$ & $* * *$ & $* * *$ \\
\hline 2 & 0.088 & - & $* * *$ & $* * *$ & $* * *$ & $* * *$ & $* * *$ & $* * *$ & $* * *$ & $* * *$ & $* * *$ & $* * *$ & $* * *$ & $* * *$ & $* * *$ & $* * *$ & $* * *$ & $* * *$ & $* * *$ & $* * *$ & $* * *$ & $* * *$ & $* * *$ & $* * *$ & $* * *$ & $* * *$ & $* * *$ & $* * *$ \\
\hline 3 & 0.096 & 0.050 & - & $*$ & NS & $* * *$ & $* * *$ & $* * *$ & $* * *$ & $* * *$ & $* * *$ & $* * *$ & $* * *$ & $* * *$ & $* * *$ & $* * *$ & $* * *$ & $* * *$ & $* * *$ & $* * *$ & $* * *$ & $* * *$ & $* * *$ & $* * *$ & $* * *$ & $* * *$ & $* * *$ & $* * *$ \\
\hline 4 & 0.106 & 0.056 & 0.016 & - & NS & $* * *$ & $* * *$ & $* * *$ & $* * *$ & $* * *$ & $* * *$ & $* * *$ & $* * *$ & $* * *$ & $* * *$ & $* * *$ & $* * *$ & $* * *$ & $* * *$ & $* * *$ & $* * *$ & $* * *$ & $* * *$ & $* * *$ & $* * *$ & $* * *$ & $* * *$ & $* * *$ \\
\hline 5 & 0.127 & 0.041 & 0.008 & -0.002 & - & $* * *$ & $* * *$ & $* * *$ & $* * *$ & $* * *$ & $* * *$ & $* * *$ & $* * *$ & $* * *$ & $* * *$ & $* * *$ & $* * *$ & $* * *$ & $* * *$ & $* * *$ & $* * *$ & $* * *$ & $* * *$ & $* * *$ & $* * *$ & $* * *$ & $* * *$ & $* * *$ \\
\hline 6 & 0.182 & 0.195 & 0.175 & 0.183 & 0.198 & - & $* * *$ & $* * *$ & $* * *$ & $* * *$ & $* * *$ & $* * *$ & $* * *$ & $* * *$ & $* * *$ & $* * *$ & $* * *$ & $* * *$ & $* * *$ & $* * *$ & $* * *$ & $* * *$ & $* * *$ & $* * *$ & $* * *$ & $* * *$ & $* * *$ & $* * *$ \\
\hline 7 & 0.209 & 0.116 & 0.112 & 0.143 & 0.114 & 0.203 & - & NS & $* *$ & NS & $* * *$ & $* *$ & $* * *$ & $* * *$ & $* * *$ & $* * *$ & $* * *$ & $* * *$ & $* * *$ & $* * *$ & $* * *$ & $* * *$ & $* * *$ & $* * *$ & $* * *$ & $* * *$ & $* * *$ & $* * *$ \\
\hline 8 & 0.191 & 0.105 & 0.096 & 0.118 & 0.089 & 0.168 & 0.002 & - & $* * *$ & $* * *$ & $* * *$ & $* * *$ & $* * *$ & $* * *$ & $* * *$ & $* * *$ & $* * *$ & $* * *$ & $* * *$ & $* * *$ & $* * *$ & $* * *$ & $* * *$ & $* * *$ & $* * *$ & $* * *$ & $* * *$ & $* * *$ \\
\hline 9 & 0.233 & 0.134 & 0.130 & 0.147 & 0.116 & 0.196 & 0.025 & 0.027 & - & NS & NS & NS & $* * *$ & $* * *$ & $* * *$ & $* * *$ & $* * *$ & $* * *$ & $* * *$ & $* * *$ & $* * *$ & $* * *$ & $* * *$ & $* * *$ & $* * *$ & $* * *$ & $* * *$ & $* * *$ \\
\hline 10 & 0.225 & 0.123 & 0.125 & 0.149 & 0.109 & 0.231 & 0.004 & 0.021 & 0.012 & - & $*$ & NS & $* * *$ & $* * *$ & $* * *$ & $* * *$ & $* * *$ & $* * *$ & $* * *$ & $* * *$ & $* * *$ & $* * *$ & $* * *$ & $* * *$ & $* * *$ & $* * *$ & $* * *$ & $* * *$ \\
\hline 11 & 0.174 & 0.092 & 0.080 & 0.101 & 0.071 & 0.185 & 0.024 & 0.024 & 0.009 & 0.020 & - & * & $* * *$ & $* * *$ & $* * *$ & $* * *$ & $* * *$ & $* * *$ & $* * *$ & $* * *$ & $* * *$ & $* * *$ & $* * *$ & $* * *$ & $* * *$ & $* * *$ & $* * *$ & $* * *$ \\
\hline 12 & 0.238 & 0.138 & 0.126 & 0.155 & 0.118 & 0.227 & 0.018 & 0.023 & 0.004 & -0.003 & 0.021 & - & $* * *$ & $* * *$ & $* * *$ & $* * *$ & $* * *$ & $* * *$ & $* * *$ & $* * *$ & $* * *$ & $* * *$ & $* * *$ & $* * *$ & $* * *$ & $* * *$ & $* * *$ & $* * *$ \\
\hline 13 & 0.303 & 0.156 & 0.174 & 0.162 & 0.165 & 0.285 & 0.116 & 0.126 & 0.115 & 0.132 & 0.124 & 0.121 & - & * & * & NS & $* * *$ & $* * *$ & $* * * *$ & $* * *$ & $* * * *$ & $* * *$ & $* * *$ & $* * *$ & $* * *$ & $* * *$ & $* * * *$ & $* * *$ \\
\hline 14 & 0.318 & 0.162 & 0.186 & 0.185 & 0.169 & 0.322 & 0.117 & 0.128 & 0.098 & 0.113 & 0.128 & 0.103 & 0.013 & - & NS & NS & $* * *$ & $* * *$ & $* * *$ & $* * *$ & $* * *$ & $* * *$ & $* * *$ & $* * *$ & $* * *$ & $* * *$ & $* * *$ & $* * *$ \\
\hline 15 & 0.307 & 0.144 & 0.175 & 0.154 & 0.150 & 0.292 & 0.135 & 0.123 & 0.104 & 0.143 & 0.119 & 0.126 & 0.017 & 0.022 & - & NS & $* * *$ & $* * *$ & $* * *$ & $* * *$ & $* * *$ & $* * *$ & $* * *$ & $* * *$ & $* * *$ & $* * *$ & $* * *$ & $* * *$ \\
\hline 16 & 0.316 & 0.141 & 0.192 & 0.171 & 0.168 & 0.315 & 0.133 & 0.134 & 0.122 & 0.144 & 0.140 & 0.137 & 0.001 & 0.006 & 0.009 & - & $* * *$ & $* * *$ & $* * *$ & $* * *$ & $* * *$ & $* * *$ & $* * *$ & $* * *$ & $* * *$ & $* * *$ & $* * *$ & $* * *$ \\
\hline 17 & 0.302 & 0.237 & 0.221 & 0.239 & 0.224 & 0.228 & 0.140 & 0.153 & 0.130 & 0.146 & 0.135 & 0.159 & 0.238 & 0.228 & 0.248 & 0.245 & - & $* * *$ & $* * *$ & $* * *$ & $* * *$ & $* * *$ & $* * *$ & $* * *$ & $* * *$ & $* * *$ & $* * *$ & $* * *$ \\
\hline 18 & 0.329 & 0.165 & 0.210 & 0.173 & 0.175 & 0.336 & 0.195 & 0.156 & 0.149 & 0.200 & 0.153 & 0.180 & 0.109 & 0.122 & 0.059 & 0.094 & 0.316 & - & $* * *$ & $* * *$ & $* * *$ & $* * *$ & $* * *$ & $* * *$ & $* * *$ & $* * *$ & $* * *$ & $* * *$ \\
\hline 19 & 0.261 & 0.103 & 0.197 & 0.195 & 0.191 & 0.285 & 0.185 & 0.179 & 0.198 & 0.209 & 0.171 & 0.223 & 0.146 & 0.170 & 0.125 & 0.122 & 0.274 & 0.204 & - & $* * *$ & $* * *$ & $* * *$ & $* * *$ & $* * *$ & $* * *$ & $* * *$ & $* * *$ & $* * *$ \\
\hline 20 & 0.222 & 0.137 & 0.184 & 0.211 & 0.178 & 0.273 & 0.137 & 0.135 & 0.127 & 0.136 & 0.089 & 0.167 & 0.238 & 0.236 & 0.213 & 0.241 & 0.209 & 0.247 & 0.176 & - & $* * *$ & $* * *$ & $* * *$ & $* * *$ & $* * *$ & $* * *$ & $* * *$ & $* * *$ \\
\hline 21 & 0.283 & 0.219 & 0.260 & 0.261 & 0.262 & 0.291 & 0.231 & 0.203 & 0.218 & 0.252 & 0.173 & 0.269 & 0.294 & 0.315 & 0.256 & 0.300 & 0.308 & 0.283 & 0.197 & 0.073 & - & NS & $* * *$ & $* * *$ & $* * *$ & $* * *$ & $* * *$ & $* * *$ \\
\hline 22 & 0.304 & 0.248 & 0.289 & 0.287 & 0.292 & 0.311 & 0.264 & 0.227 & 0.250 & 0.289 & 0.209 & 0.301 & 0.325 & 0.342 & 0.277 & 0.326 & 0.329 & 0.306 & 0.212 & 0.110 & -0.009 & - & $* * *$ & $* * *$ & $* * *$ & $* * *$ & $* * *$ & $* * *$ \\
\hline 23 & 0.267 & 0.188 & 0.232 & 0.197 & 0.208 & 0.356 & 0.240 & 0.206 & 0.218 & 0.257 & 0.166 & 0.268 & 0.276 & 0.311 & 0.220 & 0.293 & 0.345 & 0.228 & 0.233 & 0.139 & 0.131 & 0.154 & - & $* * *$ & $* * *$ & $* * *$ & $* * *$ & $* * *$ \\
\hline 24 & 0.300 & 0.251 & 0.254 & 0.257 & 0.262 & 0.118 & 0.217 & 0.168 & 0.207 & 0.247 & 0.201 & 0.224 & 0.280 & 0.322 & 0.288 & 0.311 & 0.261 & 0.325 & 0.318 & 0.293 & 0.323 & 0.351 & 0.389 & - & $* * *$ & $* * *$ & $* * *$ & $* * *$ \\
\hline 25 & 0.252 & 0.214 & 0.232 & 0.255 & 0.244 & 0.094 & 0.228 & 0.179 & 0.226 & 0.249 & 0.213 & 0.238 & 0.327 & 0.346 & 0.324 & 0.341 & 0.274 & 0.349 & 0.304 & 0.288 & 0.340 & 0.361 & 0.425 & 0.069 & - & $* * *$ & $* * *$ & $* * *$ \\
\hline 26 & 0.200 & 0.207 & 0.198 & 0.221 & 0.222 & 0.064 & 0.211 & 0.170 & 0.217 & 0.240 & 0.185 & 0.235 & 0.298 & 0.340 & 0.307 & 0.329 & 0.243 & 0.337 & 0.282 & 0.248 & 0.259 & 0.275 & 0.355 & 0.105 & 0.037 & - & $* * *$ & $* * *$ \\
\hline 27 & 0.343 & 0.332 & 0.370 & 0.394 & 0.377 & 0.237 & 0.350 & 0.296 & 0.346 & 0.371 & 0.331 & 0.369 & 0.484 & 0.489 & 0.476 & 0.489 & 0.379 & 0.508 & 0.407 & 0.342 & 0.410 & 0.428 & 0.520 & 0.236 & 0.153 & 0.179 & - & $* * *$ \\
\hline 28 & 0.301 & 0.324 & 0.330 & 0.344 & 0.358 & 0.186 & 0.314 & 0.264 & 0.312 & 0.351 & 0.294 & 0.345 & 0.437 & 0.453 & 0.431 & 0.455 & 0.316 & 0.475 & 0.372 & 0.299 & 0.314 & 0.313 & 0.458 & 0.242 & 0.185 & 0.126 & 0.156 & - \\
\hline
\end{tabular}

${ }^{* * *} P<0.001,{ }^{* *} P<0.01,{ }^{*} P<0.05$, and NS = not significant. 
Table 5 Results of simple and partial Mantel tests to investigate the relationship between $F_{\mathrm{ST}} \mathrm{s}$, straight line distance, river distance, elevation, and mountain ridges

\begin{tabular}{|c|c|c|c|c|c|c|}
\hline Region & Mantel test & $P$-value & $\begin{array}{l}\text { Bonferroni } \\
\alpha \text { value }\end{array}$ & Significance & $r$ & $r^{2}$ \\
\hline \multirow{6}{*}{ 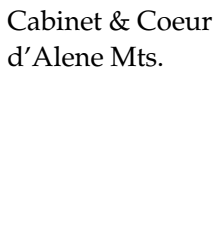 } & $F_{\mathrm{ST}} \times \ln ($ straight line dist $)$ & 0.0005 & 0.0085 & * & 0.719 & 0.517 \\
\hline & $F_{\mathrm{ST}} \times \ln ($ river dist $)$ & 0.0005 & 0.0102 & * & 0.770 & 0.593 \\
\hline & $F_{\mathrm{ST}} \times$ elevation & 0.0005 & 0.0127 & * & 0.691 & 0.478 \\
\hline & $F_{\mathrm{ST}} \times$ ridge & 0.0005 & 0.0170 & * & 0.832 & 0.692 \\
\hline & $\left(F_{\mathrm{ST}} \times\right.$ elev $) \cdot \ln ($ riv dist $)$ & 0.0005 & 0.0253 & * & 0.528 & 0.279 \\
\hline & $\left(F_{\mathrm{ST}} \times\right.$ rid $) \cdot \ln (\mathrm{SL}$ dist $)$ & 0.001 & 0.0500 & * & 0.418 & 0.175 \\
\hline \multirow[t]{6}{*}{ Bitterroot Mts. } & $F_{\mathrm{ST}} \times \ln ($ straight line dist $)$ & 0.0005 & 0.0085 & * & 0.761 & 0.580 \\
\hline & $F_{\mathrm{ST}} \times \ln ($ river dist $)$ & 0.0005 & 0.0102 & * & 0.618 & 0.382 \\
\hline & $F_{\mathrm{ST}} \times$ ridge & 0.0015 & 0.0127 & * & 0.459 & 0.210 \\
\hline & $F_{\mathrm{ST}} \times$ elevation & 0.047 & 0.0170 & NS & 0.267 & 0.071 \\
\hline & $\left(F_{\mathrm{ST}} \times\right.$ elev $) \cdot \ln ($ riv dist $)$ & 0.073 & - & NS & 0.238 & 0.057 \\
\hline & $\left(F_{\mathrm{ST}} \times\right.$ rid $) \cdot \ln (\mathrm{SL}$ dist $)$ & 0.784 & - & NS & 0.039 & 0.002 \\
\hline \multirow[t]{6}{*}{ Bighorn Crags } & $F_{\mathrm{ST}} \times \ln ($ river dist $)$ & 0.078 & 0.0085 & NS & 0.575 & 0.331 \\
\hline & $F_{\mathrm{ST}} \times$ elevation & 0.293 & - & NS & -0.377 & 0.142 \\
\hline & $F_{\mathrm{ST}} \times \ln ($ straight line dist) & 0.361 & - & NS & 0.321 & 0.103 \\
\hline & $F_{\mathrm{ST}} \times$ ridge & 0.435 & - & NS & 0.285 & 0.082 \\
\hline & $\left(F_{\mathrm{ST}} \times\right.$ elev $) \cdot \ln ($ riv dist $)$ & 0.620 & - & NS & -0.182 & 0.033 \\
\hline & $\left(F_{\mathrm{ST}} \times\right.$ rid $) \cdot \ln (\mathrm{SL}$ dist $)$ & 0.690 & - & NS & 0.144 & 0.021 \\
\hline
\end{tabular}

Four simple Mantel tests and two partial Mantel tests were performed for each region. The two partial Mantel tests are $\left(F_{\mathrm{ST}} \times\right.$ elev) $\cdot \ln ($ riv dist) which tests the partial correlation between $F_{\mathrm{ST}}$ and elevation after controlling for $\ln$ (river distance) and $\left(F_{\mathrm{ST}} \times\right.$ rid) $\cdot \ln (\mathrm{SL}$ dist) which tests the partial correlation between $F_{\mathrm{ST}}$ and ridges after controlling for $\ln$ (straight line distance). The $\alpha$ value for each test was determined by a sequential Bonferroni adjustment. * indicates a significant test and NS indicates a nonsignificant test. $r$ is the standardized Mantel test statistic which is equivalent to a Pearson product-moment correlation coefficient and $r^{2}$ is the coefficient of determination.

$F_{\mathrm{ST}} \mathrm{S}$ between a high elevation site (1) and low elevation sites (2-5) in Keeler Creek are higher than pairwise $F_{\mathrm{ST}} \mathrm{s}$ between the low elevation sites (Table 4). Similarly, the pairwise $F_{\mathrm{ST}}$ between a high elevation site (19) and low elevation site (20) in Rock Creek is high (0.176) despite being separated by only $17 \mathrm{~km}$ (Table 4 ).

Mantel tests and partial Mantel tests also reveal that straight-line distances, river distances, mountain ridges, and elevational differences tend to be positively correlated with genetic divergence, although these correlations vary by region. In the Cabinet and Coeur d' Alene Mountains, $F_{\mathrm{ST}}$ is significantly correlated with all four landscape variables and all correlations have large coefficients of determination (Table 5). Moreover, the partial correlation of $F_{\mathrm{ST}}$ and elevation is significant after controlling for the effect of $\ln$ river distance and the partial correlation of $F_{\mathrm{ST}}$ and ridges is significant after controlling for the effect of $\ln$ straight-line distance (Table 5). In the Bitterroot Mountains, $F_{\mathrm{ST}}$ is only correlated with $\ln$ straight-line distance, $\ln$ river distance, and ridges (Table 5). In the Bighorn Crags, no correlations are significant, likely because of the small number of sites, and therefore low power, in this region compared to the other two regions.

Exact tests of population differentiation and the clustering method implemented in STRUCTURE both show that popu- lations often encompass more than a single pond (Tables 4 , 6 and 7, Fig. 3). However, exact tests (Table 4) tended to split populations more finely than did the clustering method (Tables 6 and 7, Fig. 3). For example, exact tests show significant differences in allele frequencies between site 2 and the other three low elevation sites ( 3 to 5 ) in Keeler Creek, splitting the low elevation sites in Keeler into an upper and lower population (Table 4). In contrast, the clustering method identifies a total of three populations in Keeler and Stanley Creeks (Table 6) and assigns sites 2 to 5 to a single population (Table 7, Fig. 3). In another example, exact tests reveal significant differences in allele frequencies among all five sites (24 to 28 ) in the Bighorn Crags, suggesting each site is its own population (Table 4). However, the clustering method identifies a total of two populations for these five sites (Table 6) and places sites 24 to 26 in one population and sites 27 to 28 in another (Table 7, Fig. 3).

\section{Discussion}

\section{Do ridges act as barriers to gene flow?}

Our microsatellite data show that in most cases, mountain ridges act as barriers to gene flow in Columbia spotted frogs (Tables 4,5). This result suggests that dispersal rates 
Table 6 Inference of the number of populations of Columbia spotted frogs in different basins or sets of adjacent basins using the model-based clustering method of Pritchard et al. (2000)

\begin{tabular}{|c|c|c|c|}
\hline Basins & K & $\begin{array}{l}\text { Mean ln } \\
P(X \mid K)\end{array}$ & $P(K \mid X)$ \\
\hline Keeler \& Stanley & $\begin{array}{l}1 \\
2 \\
3 \\
4 \\
5 \\
6\end{array}$ & $\begin{array}{l}-2010.1 \\
-1978.9 \\
-1922.1 \\
-1938.5 \\
-2008.5 \\
-2100.0\end{array}$ & $\begin{array}{l}\sim 0.0 \\
\sim 0.0 \\
\sim \mathbf{1 . 0} \\
\sim 0.0 \\
\sim 0.0 \\
\sim 0.0\end{array}$ \\
\hline Marten & $\begin{array}{l}1 \\
2 \\
3 \\
4 \\
5 \\
6\end{array}$ & $\begin{array}{l}-2662.2 \\
-2959.9 \\
-2880.1 \\
-3490.5 \\
-3180.8 \\
-3900.6\end{array}$ & $\begin{array}{l}\sim \mathbf{1 . 0} \\
\sim 0.0 \\
\sim 0.0 \\
\sim 0.0 \\
\sim 0.0 \\
\sim 0.0\end{array}$ \\
\hline $\begin{array}{l}\text { One Horse, N. } \\
\text { Sweeney, Bitterroot, } \\
\& \text { S. Sweeney }\end{array}$ & $\begin{array}{l}1 \\
2 \\
3 \\
4 \\
5 \\
6\end{array}$ & $\begin{array}{l}-1839.8 \\
-1578.4 \\
-1548.0 \\
-1589.2 \\
-1654.3 \\
-1714.2\end{array}$ & $\begin{array}{l}\sim 0.0 \\
\sim 0.0 \\
\sim \mathbf{1 . 0} \\
\sim 0.0 \\
\sim 0.0 \\
\sim 0.0\end{array}$ \\
\hline Rock \& L. Rock & $\begin{array}{l}1 \\
2 \\
3 \\
4 \\
5\end{array}$ & $\begin{array}{l}-1097.4 \\
-1053.4 \\
-1007.3 \\
-1005.9 \\
-1121.5\end{array}$ & $\begin{array}{c}\sim 0.0 \\
\sim 0.0 \\
0.20 \\
\mathbf{0 . 8 0} \\
\sim 0.0\end{array}$ \\
\hline Skyhigh, Bob, \& Tiptop & $\begin{array}{l}1 \\
2 \\
3 \\
4 \\
5\end{array}$ & $\begin{array}{l}-1057.1 \\
-978.6 \\
-1038.8 \\
-1103.7 \\
-1061.2\end{array}$ & $\begin{array}{l}\sim 0.0 \\
\sim \mathbf{1 . 0} \\
\sim 0.0 \\
\sim 0.0 \\
\sim 0.0\end{array}$ \\
\hline
\end{tabular}

$K$ is the number of populations, $\ln P(X \mid K)$ is the $\ln$ probability of the data given $K$, and $P(K \mid X)$ is the estimated posterior probability of $K$ given the data. Five independent runs for each $K$ were used to estimate mean $\ln P(X \mid K)$. The highest $P(K \mid X)$ for each basin or set of adjacent basins is shown in bold.

over ridges are low despite the potential for long distance movements in the species (Turner 1960; Reaser 1996; Pilliod et al. 2002; Funk et al. 2005). Previous work has shown a similar isolating effect of mountain ridges on gene flow in a different frog species (Lougheed et al. 1999), suggesting that ridges may generally act as barriers to gene flow in amphibians. Our results also imply that amphibian populations in mountainous regions should show high levels of population differentiation. This prediction holds for several species of amphibians in mountains (García-Paris et al. 2000; Shaffer et al. 2000; Tallmon et al. 2000; Monsen \& Blouin 2003). The observation that ridges impede gene flow also suggests that ridges may facilitate allopatric speciation among amphibian populations (Lougheed et al. 1999).
Table 7 Mean proportion of genome from each site estimated to have originated from population $k\left(\bar{q}_{k}\right)$ in given set of adjacent basins using the admixture model of Pritchard et al. (2000)

\begin{tabular}{|c|c|c|c|c|c|}
\hline \multirow[b]{2}{*}{ Basins } & \multirow[b]{2}{*}{ Site } & \multicolumn{4}{|l|}{$k$} \\
\hline & & 1 & 2 & 3 & 4 \\
\hline \multirow{6}{*}{ Keeler \& Stanley } & 1 & 0.71 & 0.10 & 0.19 & - \\
\hline & 2 & 0.40 & 0.43 & 0.17 & - \\
\hline & 3 & 0.21 & 0.59 & 0.20 & - \\
\hline & 4 & 0.23 & 0.57 & 0.20 & - \\
\hline & 5 & 0.15 & 0.67 & 0.18 & - \\
\hline & 6 & 0.14 & 0.05 & 0.81 & - \\
\hline \multirow{6}{*}{$\begin{array}{l}\text { One Horse, } \\
\text { N. Sweeney, } \\
\text { Bitterroot, \& } \\
\text { S. Sweeney }\end{array}$} & 13 & 0.64 & 0.06 & 0.31 & - \\
\hline & 14 & 0.61 & 0.03 & 0.35 & - \\
\hline & 15 & 0.65 & 0.04 & 0.31 & - \\
\hline & 16 & 0.59 & 0.04 & 0.37 & - \\
\hline & 17 & 0.02 & 0.97 & 0.01 & - \\
\hline & 18 & 0.10 & 0.02 & 0.88 & - \\
\hline \multirow[t]{5}{*}{ Rock \& L. Rock } & 19 & 0.82 & 0.08 & 0.05 & 0.05 \\
\hline & 20 & 0.06 & 0.59 & 0.17 & 0.18 \\
\hline & 21 & 0.12 & 0.24 & 0.41 & 0.24 \\
\hline & 22 & 0.13 & 0.20 & 0.43 & 0.24 \\
\hline & 23 & 0.07 & 0.12 & 0.25 & 0.56 \\
\hline \multirow{5}{*}{$\begin{array}{l}\text { Skyhigh, } \\
\text { Bob, \& Tiptop }\end{array}$} & 24 & 0.81 & 0.19 & - & - \\
\hline & 25 & 0.71 & 0.29 & - & - \\
\hline & 26 & 0.72 & 0.28 & - & - \\
\hline & 27 & 0.18 & 0.82 & - & - \\
\hline & 28 & 0.13 & 0.87 & - & - \\
\hline
\end{tabular}

Dashes indicate that the $k^{\text {th }}$ population was not inferred for the given set of adjacent basins. Data is not shown for Marten because only one cluster was inferred for Marten (and therefore all genomes originated from $k=1$ ). Sites were assigned to the population with the highest $\bar{q}_{k}$ (Fig. 3). The highest $\bar{q}_{k}$ for each site is shown in bold.

There was one notable exception to the observation that ridges impede gene flow among Columbia spotted frog populations. In the Bitterroot Mountains, pairwise $F_{\mathrm{ST}}$ s were low between site (13) in One Horse Creek and sites (14 to 16) on the other side of a large ridge in North Fork Sweeney Creek (Table 4, Fig. 1). We suspect that this exception is a result of an exceptionally large breeding population of frogs in North Fork Sweeney Creek (Maxell, unpublished) which would be expected to result in high levels of gene flow $\left(N_{e} m\right)$ even if dispersal rates $(m)$ over the ridge are low. Because population differentiation is inversely proportional to the absolute amount of gene flow, not dispersal rates, high gene flow will lead to low pairwise $F_{\mathrm{ST}} \mathrm{s}$ (Wright 1969).

\section{Is gene flow restricted between low and high elevation ponds?}

Our microsatellite data also demonstrate that gene flow tends to be restricted between low and high elevation ponds 


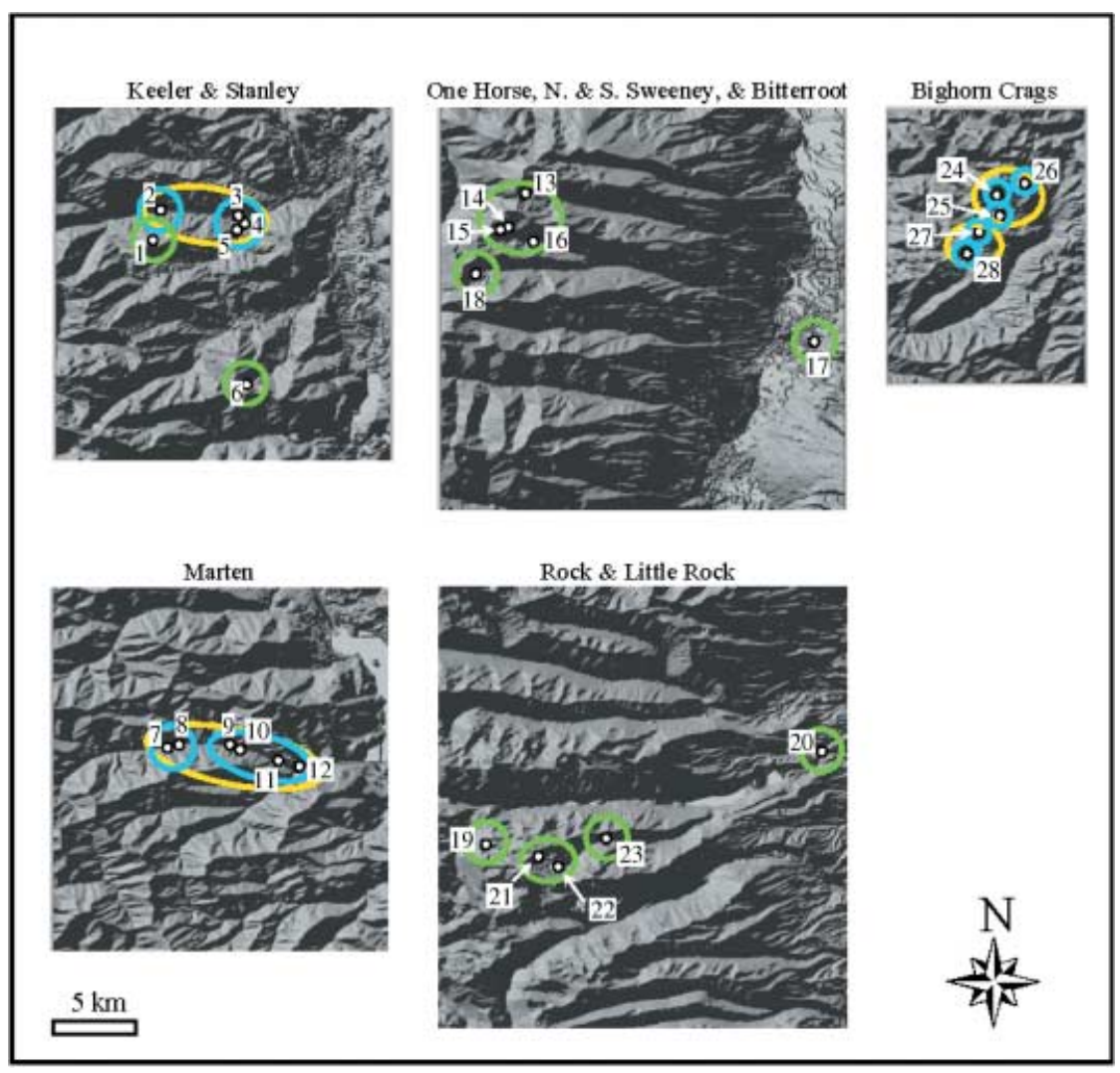

Fig. 3 Grouping of sites into populations. Green circles are populations identified by both exact tests and Pritchard et al.'s (2000) clustering algorithm, blue circles are populations identified only by exact tests, and yellow circles are populations identified only by the clustering algorithm.

in Columbia spotted frogs (Tables 4,5 ). Two alternative explanations for restricted gene flow between low and high elevations are that dispersal is restricted between low and high elevations or that there are premating barriers to gene flow between low and high elevations. Capturerecapture analysis in Columbia spotted frogs shows that dispersal rates between low and high elevation populations can be exceptionally high (Funk et al. 2005), suggesting that dispersal is not restricted between low and high elevations. This implies that there may be premating barriers to gene flow that have restricted gene flow between low and high elevations. Alternatively, the discrepancy between high dispersal and restricted gene flow between low and high elevations may be a result of unusually high dispersal during the time period of the capture-recapture study.

No significant relationship was observed between $F_{\mathrm{ST}}$ and elevational differences in the Bitterroot Mountains using Mantel tests which seems to contradict high pairwise $F_{\mathrm{ST}} \mathrm{s}$ between low and high elevation sites in this region. The reason for this apparent contradiction is that in the Bitterroot Mountains, we primarily sampled high elevation sites. Because many high elevation sites were separated by one or more mountain ridges, pairwise $F_{\mathrm{ST}} \mathrm{S}$ among high elevation sites tended to be high despite the fact that these sites were at similar elevations. This resulted in many data points in the upper left-hand quadrant (little elevational differences but high pairwise $F_{\mathrm{ST}} \mathrm{s}$ ) of the regression between $F_{\mathrm{ST}}$ and elevational differences, resulting in a nonsignificant regression. Nevertheless, high pairwise $F_{\mathrm{ST}} \mathrm{S}$ between low and high elevation sites in the Bitterroots suggest that gene flow is restricted across elevation in this region as also seen in the Cabinet Mountains.

\section{Does a pond equal a randomly mating population?}

Our microsatellite data also show that Columbia spotted frog populations usually encompass more than a single breeding pond. In most cases, populations are made up of multiple ponds within a basin (Fig. 3). Some basins only contain a single population, whereas other basins contain two (Fig. 3). In the cases where ponds or lakes are equivalent to populations, usually the ponds or lakes are very isolated from other ponds by distance, mountain ridges, or elevation (sites 1, 6, 18, and 19). Low elevation sites 17 and 20 in the Bitterroot Mountains region are identified as discrete populations, but this is likely because of the fact that we did not sample adjacent, low elevation sites. Moreover, in pond 7, three pairs of loci were in linkage disequilibrium, suggesting that there may be some degree of population subdivision within this pond. One explanation for population subdivision in pond 7 is a recent influx of immigrants into pond 7 from a pond with significantly different allele frequencies. In cases where ponds are equivalent to populations, we emphasize that 
terrestrial habitat surrounding ponds must also be protected in addition to ponds (Semlitsch 2003).

A notable exception to the generalization that most populations are contained within basins is sites 13 to 16 which represent a single population despite being located in two different basins (Fig. 3). As explained previously, we suspect this is a result of a very large breeding aggregation of frogs in North Fork Sweeney Creek (sites 14 to 16) causing high gene flow from North Fork Sweeney Creek into One Horse Creek (site 13). Nonetheless, the observation that most basins contain one or two populations of Columbia spotted frogs and that most populations are bounded by a single basin suggests that basins in the size range studied here (a few to several kilometers long) may be appropriate geographical units for management of this species.

Exact tests often split populations more finely than did the clustering method in STRUCTURE (Fig. 3). This is expected because allele frequency differences (tested with exact tests) will likely become manifest sooner than Hardy-Weinberg or linkage disequilibrium (tested by the clustering method) after population subdivision. The question then arises: which method is better for identifying 'randomly mating populations'? We argue that neither is better, but that they measure population subdivision in different ways. We therefore suggest that they should be used together to delineate populations. Specifically, we recommend using the clustering method as an upper estimate of the number of ponds per population and exact tests as a lower estimate.

\section{Negative relationship between genetic variation within populations and elevation}

A striking result of this study was the strong, negative relationship between genetic variation within sites and elevation across all 28 sites sampled (Fig. 2). Correlation coefficients between expected heterozygosity and elevation $(r=-0.88)$ and between allelic richness and elevation $(r=$ $-0.85)$ were both very large and highly significant $(P<0.001)$. This observation suggests that effective population sizes $\left(N_{e}\right)$ are much smaller at high elevations than at low elevations in Columbia spotted frogs. Effective population sizes may be smaller at high elevations either because local $N_{e}{ }^{\prime}$ s are smaller or because gene flow is restricted at high elevations. Our data suggest that gene flow is restricted by mountain ridges at high elevations and between low and high elevation sites, supporting the latter hypothesis. Moreover, some high elevation ponds such as ponds 14 to 16 (Fig. 1) support very large breeding aggregations, suggesting that local $N_{e}{ }^{\prime} \mathrm{s}$ can be large at high elevations (Maxell, unpublished).

\section{Valley-mountain model of population structure}

Columbia spotted frogs have a fairly consistent population structure across all three regions analysed in this study which

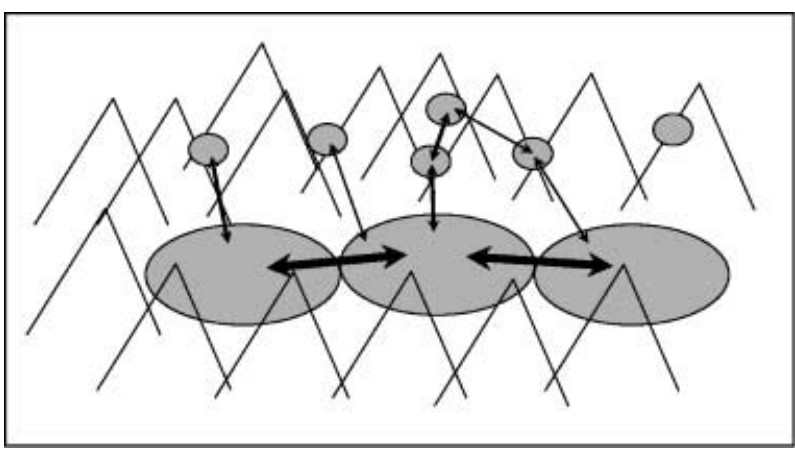

Fig. 4 'Valley-mountain' model of population structure for Columbia spotted frogs. This population structure has three distinct characteristics: (i) low elevation populations with large historic effective population sizes (large circles) and high levels of among population gene flow (thick arrows); (ii) high elevation populations with small historic effective population sizes (small circles) and little (thin and medium arrows) to no among population gene flow; and (iii) gene flow tends to be restricted between low and high elevation populations (thin and medium arrows).

we refer to as a 'valley-mountain' population structure (Fig. 4). This population structure has three distinct characteristics. First, low elevation populations have large historic effective population sizes and high levels of among population gene flow. Second, high elevation populations have small historic effective population sizes and lower levels of among population gene flow, as has been shown previously in long-toed salamanders (Ambystoma macrodactylum) in the Bitterroot Mountains (Funk et al. 1999; Tallmon et al. 2000). Third, gene flow is restricted, but not absent, between low and high elevation populations. The valley-mountain population structure may be typical of other amphibian species inhabiting similar landscapes, but only future studies with appropriate sampling strategies can test the generality of this pattern.

The valley-mountain model of population structure has at least two important evolutionary implications for Columbia spotted frogs. First, restricted gene flow between low and high elevation sites should facilitate local adaptation to these very different habitats. Second, high elevation populations separated by mountain ridges may have largely independent evolutionary trajectories compared to low elevation populations which are much more connected by gene flow.

The valley-mountain model of population structure also has several important implications for conservation of Columbia spotted frogs. First, small effective population sizes and isolation may make high elevation populations particularly susceptible to extinction (Newman \& Pilson 1997; Saccheri et al. 1998). Second, because low elevation populations have been historically connected by dispersal and gene flow, isolation of low elevation populations through habitat fragmentation may increase local extinction 
rates by decreasing the potential for rescue effects (Brown \& Kodric-Brown 1977; Funk et al. 2005). Next, connectivity between low and high elevation populations by dispersal and gene flow may be important for the persistence (Brown \& Kodric-Brown 1977; Newman \& Tallmon 2001) and recolonization (Levins 1969; Funk \& Dunlap 1999) of high elevation populations. Although our analyses suggest that gene flow is restricted between low and high elevation populations, low elevation populations may often be the primary source of immigrants to high elevation populations.

Moreover, if low elevation populations are important sources of immigrants and genetic variation for high elevation populations, then extinction of low elevation populations may have the unexpected consequence of reducing the persistence of mountain populations. In other words, if the low elevation 'mainland' is destroyed, eventually there may be nothing left but high elevation 'islands.' This is not an unrealistic possibility given that low elevation valley populations of amphibians are often the first to be impacted by habitat loss, fragmentation, and the introduction of exotic species. For example, almost all low elevation populations of Oregon spotted frogs (Rana pretiosa) have been eliminated from the Willamette Valley of Oregon and the Puget Trough of Washington (Green et al. 1997) and populations of the California red-legged frog (Rana aurora draytonii) are also largely extinct from the Central Valley of California (Drost \& Fellers 1996; Davidson et al. 2001). Similarly, Columbia spotted frogs are becoming increasingly difficult to find in low elevation valleys in western Montana, likely because of the introduction of exotic American bullfrogs (Rana catesbeiana) and exotic fishes as well as habitat loss and fragmentation (Maxell et al. 2003). Predicting the persistence of high elevation amphibian populations thus requires an understanding of historical connectivity between low and high elevation populations.

\section{Acknowledgements}

This project was funded by the US Department of the Interior's Amphibian Research and Monitoring Initiative and seed grants from the Declining Amphibian Populations Task Force to W.C.F. \& B.A.M.; W.C.F. was also funded by a National Science Foundation Graduate Research Fellowship (DGE 9616153), the National Science Foundation Training-WEB (DGE 9553611), and Bertha Morton Scholarships from the University of Montana. We thank S. Adams, R. Benson, B. Bentz, G. Brownworth, C. Crowder, A. Greene, N. Johnson, C. Kim, P. Lizon, C. Richey, and several volunteers for help with tissue collection and Rodd Gallaway and Jill Davies for field accommodations. We thank K. Knudsen, P. Spruell, and A. Whiteley for laboratory support and advice. We thank B. Hossack for help with maps. We also thank L. Fishman, S. Mills, A. Sheldon, M. Schwartz, and three anonymous reviewers for comments on earlier versions of this manuscript. This project was approved by the Animal Care and Use Committee at the University of Montana (ACC 016-00). This is publication number 73 of the Yanayacu Natural History Research Group.

\section{References}

Alford RA, Richards SJ (1999) Global amphibian declines: a problem in applied ecology. Annual Review of Ecology and Systematics, 30, 133-165.

Berry O (2001) Genetic evidence for wide dispersal by the sand frog, Heleioporus psammophilus (Anura: Myobatrachidae), in Western Australia. Journal of Herpetology, 35, 136-141.

Berven KA, Grudzien TA (1990) Dispersal in the wood frog (Rana sylvatica): implications for genetic population structure. Evolution, 44, 2047-2056.

Blaustein AR, Wake DB, Sousa WP (1994) Amphibian declines: judging stability, persistence, and susceptibility of populations to local and global extinctions. Conservation Biology, 8, $60-71$.

Bockelmann A-C, Reusch TBH, Bijlsma R, Bakker JP (2003) Habitat differentiation vs. isolation-by-distance: the genetic population structure of Elymus athericus in European salt marshes. Molecular Ecology, 12, 505-515.

Bos DH, Sites JW Jr (2001) Phylogeography and conservation genetics of the Columbia spotted frog (Rana luteiventris; Amphibia, Ranidae). Molecular Ecology, 10, 1499-1513.

Breden F (1987) The effect of post-metamorphic dispersal on the population genetic structure of Fowler's toad, Bufo woodhousei fowleri. Copeia, 1987, 386-395.

Brown JH, Kodric-Brown A (1977) Turnover rates in insular biogeography: effect of immigration on extinction. Ecology, 58, 445-449.

Daugherty CH, Sheldon AL (1982) Age-specific movement patterns of the frog Ascaphus truei. Herpetologica, 38, 468-474.

Davidson C, Shaffer HB, Jennings MR (2001) Declines of the California red-legged frog: climate, UV-B, habitat, and pesticides hypotheses. Ecological Applications, 11, 464-479.

Driscoll DA (1997) Mobility and metapopulation structure of Geocrinia alba and Geocrinia vitellina, two endangered frog species from southwestern Australia. Australian Journal of Ecology, 22, 185-195.

Driscoll DA (1998) Genetic structure, metapopulation processes and evolution influence the conservation strategies for two endangered frog species. Biological Conservation, 83, 43-54.

Drost CA, Fellers GM (1996) Collapse of a regional frog fauna in the Yosemite area of the California Sierra Nevada, USA. Conservation Biology, 10, 414-425.

Duellman WE, Trueb L (1994) The Biology of Amphibians. Johns Hopkins University Press, Baltimore, Maryland.

Excoffier L, Smouse PE, Quattro JM (1992) Analysis of molecular variance inferred from metric distances among DNA haplotypes: application to human mitochondrial DNA restriction data. Genetics, 131, 479-491.

Funk WC, Dunlap WW (1999) Colonization of high-elevation lakes by long-toed salamanders (Ambystoma macrodactylum) after the extinction of introduced trout populations. Canadian Journal of Zoology, 77, 1759-1767.

Funk WC, Greene AE, Corn PS, Allendorf FW (2005) High dispersal in a frog species suggests that it is vulnerable to habitat fragmentation. Biology Letters.

Funk WC, Tallmon DA, Allendorf FW (1999) Small effective population size in the long-toed salamander. Molecular Ecology, 8, 1633-1640.

García-Paris M, Good DA, Parra-Olea G, Wake DB (2000) Biodiversity of Costa Rican salamanders: Implications of high levels of genetic differentiation and phylogeographic structure for 
species formation. Proceedings of the National Academy of Sciences of the United States of America, 97, 1640-1647.

Geffen E, Anderson MJ, Wayne RK (2004) Climate and habitat barriers to dispersal in the highly mobile grey wolf. Molecular Ecology, 13, 2481-2490.

Gill DE (1978) The metapopulation ecology of the red-spotted newt, Notophthalmus viridescens (Rafinesque). Ecological Monographs, 48, 145-166.

Goudet J (1995) FSTAT, (version 1.2): a computer program to calculate F-statistics. Journal of Heredity, 86, 485-486.

Green DM, Kaiser H, Sharbel TF, Kearsley J, McAllister KR (1997) Cryptic species of spotted frogs, Rana pretiosa complex, in western North America. Copeia, 1997, 1-8.

Green DM, Sharbel TF, Kearsley J, Kaiser H (1996) Postglacial range fluctuation, genetic subdivision and speciation in the western North American spotted frog complex, Rana pretiosa. Evolution, 50, 374-390.

Hartl DL, Clark AG (1989) Principles of Population Genetics, 2nd edn, Sinauer Associates, Inc, Sunderland, Massachusetts.

Hecnar SJ, M'Closkey RT (1996) Regional dynamics and the status of amphibians. Ecology, 77, 2091-2097.

Heyer WR, Donnelly MA, McDiarmid RW, Hayek LAC, Foster MS (1994) Measuring and Monitoring Biology Diversity. Standard Methods for Amphibians. Smithsonian Institution Press, Washington, DC, USA

Howard JH, Wallace RL (1985) Life history characteristics of populations of the long-toed salamander (Ambystoma macrodactylum) from different altitudes. American Midland Naturalist, 113, 361373.

Keyghobadi N, Roland J, Strobeck C (1999) Influence of landscape on the population genetic structure of the alpine butterfly Parnassius smintheus (Papilionidae). Molecular Ecology, 8, 14811495.

Lampert KP, Rand AS, Mueller UG, Ryan MJ (2003) Fine-scale genetic pattern and evidence for sex-biased dispersal in the túngara frog, Physalaemus pustulosus. Molecular Ecology, 12, 33253334.

Larson A, Wake DB, Yanev KP (1984) Measuring gene flow among populations having high levels of genetic fragmentation. Genetics, 106, 293-308.

Levins R (1969) Some demographic and genetic consequences of environmental heterogeneity for biological control. Bulletin of the Entomological Society of America, 15, 237-240.

Lougheed SC, Gascon C, Jones DA, Bogart JP, Boag PT (1999) Ridges and rivers: a test of competing hypotheses of Amazonian diversification using a dart-poison frog (Epipedobates femoralis). Proceedings of the Royal Society of London Series B, Biological Sciences, 266, 1829-1835.

Lüddecke H, Sánchez OR (2002) Are tropical highland frog calls cold-adapted? The case of the Andean frog Hyla labialis. Biotropica, 34, 281-288.

Lynch JD, Duellman WE (1997) Frogs of the genus Eleutherodactylus (Leptodactylidae) in western Ecuador: systematics, ecology, and biogeography. Natural History Museum, University of Kansas. Special Publications, 23, 1-236.

Manel S, Schwartz MK, Luikart G, Taberlet P (2003) Landscape genetics: combining landscape ecology and population genetics. Trends in Ecology and Evolution, 18, 189-197.

Mantel N (1967) The detection of disease clustering and a generalized regression approach. Cancer Research, 27, 209-220.

Marsh DM, Trenham PC (2001) Metapopulation dynamics and amphibian conservation. Conservation Biology, 15, 40-49.
Maxell BA, Werner JK, Hendricks P, Flath DL (2003) Herpetology in Montana: a history, status summary, checklists, dichotomous keys, accounts for native, potentially native, and exotic species, and indexed bibliography. Northwest Fauna, 5, 1-138.

Monsen KJ, Blouin MS (2003) Genetic structure in a montane ranid frog: restricted gene flow and nuclear-mitochondrial discordance. Molecular Ecology, 12, 3275-3286.

Moritz C (1994) Defining 'Evolutionarily Significant Units' for conservation. Trends in Ecology and Evolution, 9, 373-375.

Narins PM, Smith SL (1986) Clinal variation in anuran advertisement calls: basis for acoustical isolation? Behavioral Ecology and Sociobiology, 19, 135-141.

Newman D, Pilson D (1997) Increased probability of extinction due to decreased genetic effective population size: experimental populations of Clarkia pulchella. Evolution, 51, 354-362.

Newman RA, Squire T (2001) Microsatellite variation and finescale population structure in the wood frog (Rana sylvatica). Molecular Ecology, 10, 1087-1100.

Newman D, Tallmon DA (2001) Experimental evidence for beneficial fitness effects of gene flow in recently isolated populations. Conservation Biology, 15, 1054-1063.

Petit RJ, El Mousadik A, Pons O (1998) Identifying populations for conservation on the basis of genetic markers. Conservation Biology, 12, 844-855.

Pilliod DS, Peterson CR, Ritson PI (2002) Seasonal migration of Columbia spotted frogs (Rana luteiventris) among complementary resources in a high mountain basin. Canadian Journal of Zoology, 80, 1849-1862.

Pritchard JK, Stephens M, Donnelly P (2000) Inference of population structure using multilocus genotype data. Genetics, 155 945-959.

Raymond M, Rousset F (1995) GENEPOP (version 1.2): a population genetics software for exact tests and ecumenicism. Journal of Heredity, 83, 248-249.

Reaser JK (1996) Rana pretiosa (spotted frog). Vagility. Herpetological Review, 27, 196-197.

Rice WR (1989) Analyzing tables of statistical tests. Evolution, 43, 223-225.

Saccheri I, Kuussaari M, Kankare M et al. (1998) Inbreeding and extinction in a butterfly metapopulation. Nature, 392, 491-494.

Schneider S, Roessli D, Excoffier L (2000) ARLEQUIN, version 2.001: A Software for Population Genetics Data Analysis. Genetics and Biometry Laboratory. University of Geneva, Switzerland.

Semlitsch RD (2003) Conservation of pond-breeding amphibians. In: Amphibian Conservation (ed. Semlitsch RD), pp. 8-23. Smithsonian Institution, Washington DC.

Shaffer HB, Fellers GM, Magee A, Voss SR (2000) The genetics of amphibian declines: population substructure and molecular differentiation in the Yosemite toad, Bufo canorus (Anura, Bufonidae) based on single-strand conformation polymorphism analysis (SSCP) and mitochondrial DNA sequence data. Molecular Ecology, 9, 245-257.

Sjögren P (1991) Extinction and isolation gradients in metapopulations: the case of the pool frog (Rana lessonae). Biological Journal of the Linnean Society, 42, 135-147.

Smith TB, Wayne RK, Girman DJ, Bruford MW (1997) A role for ecotones in generating rainforest biodiversity. Science, 276, 1855-1857.

Smouse PE, Long JC, Sokal RR (1986) Multiple regression and correlation extensions of the Mantel test of matrix correspondence. Systematic Zoology, 35, 627-632.

Sokal RR, Rohlf FJ (1981) Biometry, 2nd edn, W.H. Freeman, New York. 
496 W. C. FUNK ET AL.

Squire T, Newman RA (2002) Fine-scale population structure in the wood frog (Rana sylvatica) in a northern woodland. Herpetologica, 58, 119-130.

Tallmon DT, Funk WC, Dunlap WW, Allendorf FW (2000) Genetic differentiation among long-toed salamander (Ambystoma macrodactylum) populations. Copeia, 2000, 27-35.

Trenham PC, Koenig WD, Shaffer HB (2001) Spatially autocorrelated demography and interpond dispersal in the salamander Ambystoma californiense. Ecology, 82, 3519-3530.

Turner FB (1960) Population structure and dynamics of the western spotted frog, Rana p. pretiosa Baird \& Girard, in Yellowstone Park, Wyoming. Ecological Monographs, 30, 251-278.

Wallace AR (1852) On the monkeys of the Amazon. Proceedings of the Zoological Society of London, 20, 107-110.

Wright S (1969) Evolution and the Genetics of Populations, Vol. 2. The Theory of Gene Frequencies. University of Chicago Press, Chicago.
This study was conducted as part of W. Chris Funk's dissertation research at the University of Montana on the patterns and consequences of dispersal and gene flow in Columbia spotted frogs. W. Chris Funk is currently a Postdoctoral Fellow at the University of Texas investigating the diversification of Amazonian frogs. Michael Blouin is a professor of evolutionary genetics at Oregon State University. Paul Stephen Corn is a Research Zoologist for the USGS Biological Resources Division investigating amphibian declines in the Rocky Mountains. Bryce Maxell and Stephen Amish are graduate students at the University of Montana studying the ecology, demography, and genetics of Columbia spotted frogs. David Pilliod is a Postdoctoral Research Ecologist for the USDA Forest Service Rocky Mountain Research Station with interests in aquatic ecology and amphibian conservation. Fred Allendorf is a professor of evolutionary genetics at the University of Montana. 